\title{
NUTRIENT CONTENT IN SUNFLOWERS IRRIGATED WITH OIL EXPLORATION WATER ${ }^{1}$
}

\author{
ADERVAN FERNANDES SOUSA ${ }^{2 *}$, LINDBERGUE ARAÚJO CRISOSTOMO ${ }^{3}$, OLMAR BALLER WEBER $^{3}$, MARIA \\ EUGENIA ORTIZ ESCOBAR ${ }^{4}$, TEÓGENES SENNA DE OLIVEIRA ${ }^{5}$
}

\begin{abstract}
Irrigation using produced water, which is generated during crude oil and gas recovery and treated by the exploration industry, could be an option for irrigated agriculture in semiarid regions. To determine the viability of this option, the effects of this treated water on the nutritional status of plants should be assessed. For this purpose, we examined the nutritional changes in sunflowers after they were irrigated with oil-produced water and the effects of this water on plant biomass and seed production. The sunflower cultivar BRS 321 was grown for three crop cycles in areas irrigated with filtered produced water (FPW), reverse osmosis-treated produced water (OPW), or ground water (GW). At the end of each cycle, roots, shoots, and seeds were collected to examine their nutrient concentrations. Produced water irrigation affected nutrient accumulation in the sunflower plants. OPW irrigation promoted the accumulation of $\mathrm{Ca}, \mathrm{Na}, \mathrm{N}, \mathrm{P}$, and $\mathrm{Mg}$. FPW irrigation favored the accumulation of $\mathrm{Na}$ in both roots and shoots, and biomass and seed production were negatively affected. The $\mathrm{Na}$ in the shoots of plants irrigated with FPW increased throughout the three crop cycles. Under controlled conditions, it is possible to reuse reverse osmosis-treated produced water in agriculture. However, more long-term research is needed to understand its cumulative effects on the chemical and biological properties of the soil and crop production.
\end{abstract}

Keywords: Residual water. Salinity. Produced water. Nutrient availability.

\section{TEORES DE NUTRIENTES EM GIRASSOL IRRIGADO COM ÁGUA DA INDÚSTRIA DE PETRÓLEO}

RESUMO - Irrigação com água produzida, que é gerada durante a extração de petróleo bruto e gás pode ser uma opção para agricultura irrigada em regiões semi-áridas mas o efeito desta água tratada no estado nutricional das plantas e no crescimento e desenvolvimento das culturas deve ser avaliado. Com esse propósito, determinamos alterações nos aspectos nutricionais da cultura de girassol irrigado com água produzida e os efeitos na produção de biomassa e de grãos de girassol. O girassol cv. BRS 321 foi cultivado durante três ciclos em áreas irrigadas com água produzida filtrada (FPW) e tratada por osmose (OPW) e água subterrânea (GW). Ao final de cada ciclo, raízes, parte aérea e grãos foram coletados para determinar as concentrações de nutrientes. Irrigação com água produzida afetou o acúmulo de nutrientes em plantas de girassol. Irrigação com OPW promoveu acúmulo de $\mathrm{Ca}, \mathrm{Na}, \mathrm{N}, \mathrm{P}$ e Mg. Plantas irrigadas com FPW acumularam maiores teores de $\mathrm{Na}$ em raízes e parte aérea, e afetou negativamente a produção de biomassa e de grãos de girassol. Os níveis de $\mathrm{Na}$ na parte aérea de plantas irrigadas com FPW aumentaram ao longo dos três ciclos de cultivo. Sob condições controladas, é possível reutilizar a água produzida tratada por osmose inversa na agricultura, mas necessita de mais estudos a longo prazo para compreender o efeito cumulativo, nas propriedades químicas e biológicas do solo e na produção das culturas. Estes resultados sugerem que a irrigação com água produzida tratada adequadamente, é uma boa estratégia para a sustentabilidade dos recursos hídricos.

Palavras-chave: Água residuária. Salinidade. Água produzida. Disponibilidade de nutrientes.

\footnotetext{
*Corresponding author

${ }^{1}$ Received for publication in $03 / 31 / 2015$; accepted in $01 / 08 / 2016$

Paper extracted from the doctoral thesis of the first author.

${ }^{2}$ Department of Biological Sciences, Universidade Estadual do Ceará, Fortaleza, CE, Brazil; adervansousa@yahoo.com.br.

${ }^{3}$ Embrapa Agroindústria Tropical, Fortaleza, CE, Brazil; lindbergue.crisostomo@embrapa.br, olmar.weber@embrapa.br.

${ }^{4}$ Department of Soil Science, Universidade Federal do Ceará, Fortaleza, CE, Brazil; mariaeugenia@ufc.br.

${ }^{5}$ Department of Soil Science, Universidade Federal de Viçosa, Viçosa, MG, Brazil; teo@ufv.br.
} 


\section{INTRODUCTION}

Globally, $70 \%$ of withdrawn surface and groundwater is used for agriculture (FRENKEN; $\mathrm{KIERSCH}, 2011$ ), and so in an effort to conserve water, it is necessary to assess the use of wastewater in agricultural production (CHATZAKIS et al., 2011; CIRELLI et al. 2012).

Wastewater irrigation can raise the levels of nutrients and organic matter in the soil (XU et al., 2010; SINGH et al., 2012; BEDBABIS et al. 2014; KHAJANCHI-LAL; MINHAS; YADAV, 2015) and the macronutrients in plant tissues (KIZILOGLU et al., 2008; PEREIRA et al., 2011; RODDA et al., 2011). Both of these may have a positive effect on agricultural production. However, heavy metals and salts may also accumulate in soils and plant tissues and reach toxic levels (MORUGÁN-CORONADO et al., 2011; PEREIRA et al., 2011; RODDA et al., 2011; SOU/DAKOURÉ et al., 2013; BEDBABIS et al. 2014). The high uptake of salt by plants is the main issue with the use of wastewater irrigation (PEREIRA et al., 2011; MORUGÁN-CORONADO et al., 2011), as high levels of $\mathrm{Na}$ decrease the accumulation of nutrients in plants (PEREIRA et al., 2011; SHAHBAZ et al., 2011)

Water is essential for the environment, controlling many soil processes and nutrient availability. Thus, in order to use wastewater in agriculture appropriately, more information is needed to establish an irrigation management program. Past studies on wastewater use have primarily focused on the reuse of water from industrial sources. To our knowledge, there is no information on the reuse of wastewater obtained from oil wells (produced water) in agriculture, which, after it is treated, can be an attractive option, especially in regions where water is scarce.

Produced water usually has high concentrations of metals, salts, organic and inorganic compounds, and added chemical compounds (NASCIMENTO et al., 2006; AL-HALEEM; ABDULAH; SAEED, 2010). Therefore, it cannot be discarded directly into the environment in large quantities, and it cannot be reused because its chemical composition does not meet current environmental standards (NASCIMENTO et al., 2006). Faced with this problem, the industry has developed effluent treatment technologies to allow for the surface disposal or reuse of produced water in the irrigation of crops grown for biodiesel (MELO et al., 2010).

The possibility that produced water can be reused in agriculture by means of irrigation is of interest to the oil industry and farmers, particularly those in semiarid regions, such as northeastern Brazil. Thus, we aimed to evaluate the nutritional changes in sunflowers (Helianthus annuus) BRS 321 after they were irrigated with oil produced water and the effects of the produced water on the sunflowers' biomass and seed production in Ceará, Brazil.

\section{MATERIAL AND METHODS}

The experimental area belongs to the Brazilian Petroleum Company (PETROBRAS) and is located on Belém Farm, Aracati-CE municipality $\left(4^{\circ} 43^{\prime} 6^{\prime \prime} \mathrm{S} 37^{\circ} 32^{\prime} 48^{\prime \prime} \mathrm{W}\right)$, a semiarid region of Brazil. The annual average rainfall and temperature in the region are $949.2 \mathrm{~mm}$ and $28^{\circ} \mathrm{C}$, respectively. The soil is an Arenosol.

The wastewater derived from oil extraction was subjected to two treatments. First, the water was separated from the oil and clarified by passing it through sand filters, and then a cation resin was applied to the water to remove the lye residue remaining from the separation process (FPW). Then, the FPW underwent a chemical treatment for $\mathrm{pH}$ correction, flocculation for possible solutes, and the elimination of microorganisms that affect the extraction of oil, followed by reverse osmosis (OPW). Groundwater was used as a control, taken from the Açu aquifer via a well $250 \mathrm{~m}$ in depth $(\mathrm{GW})$. The main chemical characteristics of the different types of water are shown in Table 1.

The sunflower cultivar BRS 321 was cultivated throughout three successive crop cycles in plots of $400 \mathrm{~m}^{2}(20 \times 20 \mathrm{~m})$ and drip irrigated with three types of water in a completely randomized design $(3 \times 3)$, with three replications. The first cycle (C1) lasted from July to October 2012; the second (C2) from March to June 2013; and the third (C3) from August to November 2013. A drip irrigation system was used, and the amount of water applied was estimated using small plastic lysimeters $(0.4 \mathrm{~m}$ diameter and $0.6 \mathrm{~m}$ height), taking into account the evapotranspiration rates and losses to drainage.

The area was prepared by adding $7.5 \mathrm{~kg} \mathrm{~m}^{-2}$ for the first cycle and $2.5 \mathrm{~kg} \mathrm{~m}^{-2}$ for the second and third cycles of the following mixture (in $\mathrm{g} \mathrm{kg}^{-1}$ ): $\mathrm{C}=$ $7.3, \mathrm{P}=71.3, \mathrm{~K}=73.6, \mathrm{Ca}=179.2 \mathrm{Mg}=22.6$, and $\mathrm{Na}=22.5$. Based on the results of the soil analysis (data not shown) chemical fertilizer was added at a rate of $80 \mathrm{~kg} \mathrm{ha}^{-1} \mathrm{P}_{2} \mathrm{O}_{5}$ as superphosphate and $40 \mathrm{~kg}$ $\mathrm{ha}^{-1} \mathrm{~K}_{2} \mathrm{O}$ as potassium chloride. The organic and chemical fertilizers were incorporated into the soil at a depth of $0.15 \mathrm{~m}$. Additionally, we applied a topdressing 30 days after planting, using $50 \mathrm{~kg} \mathrm{ha}^{-1}$ of nitrogen in the form of urea.

At the end of each of the crop cycles, six plants were collected, and the roots, shoots (stem, leaves and floral party), and seeds were separated. Fractions of these samples were dried at $65^{\circ} \mathrm{C}$ to a constant weight to determine the levels of macronutrients and to evaluate the dry biomass and seed production. In extracts obtained from dry digestion, $\mathrm{Ca}$ and $\mathrm{Mg}$ content were determined using atomic absorption spectrophotometry (Perkin-Elmer Analyst 400). In the extracts obtained from nitric- 
perchloric acid digestion, the $\mathrm{Na}$ and $\mathrm{K}$ were determined by flame photometry (DM-62 Digimed), and $\mathrm{P}$ and $\mathrm{S}$ were determined colorimetrically using a spectrophotometer $(600$
FEMTO Pl $\mu \mathrm{s})$. $\mathrm{N}_{-} \mathrm{NO}_{3}$ was determined by vapor distillation drag (the Kjeldahl method), which is the method of analysis suggested by Silva (2009).

Table 1. Chemical attributes of the water used for sunflower irrigation.

\begin{tabular}{|c|c|c|c|}
\hline & OPW & FPW & GW \\
\hline & Mean & Mean & Mean \\
\hline \multicolumn{4}{|c|}{ Chemical attributes* } \\
\hline $\mathrm{EC}\left(\mathrm{dS} \cdot \mathrm{m}^{-1}\right)$ & 0.52 & 2.67 & 0.69 \\
\hline $\mathrm{pH}$ & 7.54 & 8.46 & 8.11 \\
\hline SAR & 42.90 & 39.83 & 22.60 \\
\hline $\mathrm{Na}\left(\mathrm{mg} \mathrm{dm}^{-3}\right)$ & 87.59 & 406.92 & 155.87 \\
\hline $\mathrm{K}\left(\mathrm{mg} \mathrm{dm}^{-3}\right)$ & 14.47 & 554.44 & 32.45 \\
\hline $\mathrm{Ca}\left(\mathrm{mg} \mathrm{dm}^{-3}\right)$ & 1.80 & 3.20 & 4.40 \\
\hline $\operatorname{Mg}\left(\mathrm{mg} \mathrm{dm}^{-3}\right)$ & 1.58 & 3.65 & 1.58 \\
\hline $\mathrm{Cl}\left(\mathrm{mg} \mathrm{dm}^{-3}\right)$ & 87.92 & 628.17 & 116.63 \\
\hline $\mathrm{HCO}_{3}\left(\mathrm{mg} \mathrm{dm}^{-3}\right)$ & 76.25 & 214.11 & 170.19 \\
\hline \multicolumn{4}{|l|}{ Heavy metals** } \\
\hline $\mathrm{Ag}\left(\mu \mathrm{g} \mathrm{dm}^{-3}\right)$ & $<0.70$ & $<0.70$ & $<0.70$ \\
\hline As $\left(\mu \mathrm{g} \mathrm{dm} \mathrm{m}^{-3}\right)$ & $<0.40$ & 2.08 & 0.98 \\
\hline $\mathrm{Hg}\left(\mu \mathrm{g} \mathrm{dm}^{-3}\right)$ & 0.75 & 0.40 & 0.45 \\
\hline $\left.\mathrm{B}(\mu \mathrm{g} \mathrm{dm})^{-3}\right)$ & 284.47 & 385.56 & 160.92 \\
\hline $\mathrm{Ba}\left(\mu \mathrm{g} \mathrm{dm}{ }^{-3}\right)$ & 25.19 & 155.42 & 110.30 \\
\hline $\mathrm{Cd}\left(\mu \mathrm{g} \mathrm{dm}^{-3}\right)$ & $<0.80$ & $<0.80$ & $<0.80$ \\
\hline $\mathrm{Co}\left(\mu \mathrm{g} \mathrm{dm}^{-3}\right)$ & $<1.20$ & $<1.20$ & $<1.20$ \\
\hline $\operatorname{Cr}\left(\mu \mathrm{g} \mathrm{dm}^{-3}\right)$ & $<2.50$ & $<2.50$ & $<2.50$ \\
\hline $\mathrm{Ni}\left(\mu \mathrm{g} \mathrm{dm}{ }^{-3}\right)$ & 2.50 & 1.66 & 2.51 \\
\hline $\mathrm{Pb}\left(\mu \mathrm{g} \mathrm{dm}{ }^{-3}\right)$ & 8.00 & 11.41 & 6.52 \\
\hline $\mathrm{Zn}\left(\mu \mathrm{g} \mathrm{dm} \mathrm{dm}^{-3}\right)$ & 31.31 & 8.41 & 2.95 \\
\hline
\end{tabular}

*(Mean of $\mathrm{n}=17) ;{ }^{* *}$ (Mean of $\mathrm{n}=5$ ); EC, electrical conductivity; SAR, sodium adsorption ratio. Filtered water (FPW); osmosis water (OPW); underground water (GW).

Shapiro-Wilk's test of normality and Bartlett's test for homogeneity of variance were used to analyze the data. For parametric data, we used an analysis of variance (ANOVA) and mean values of the different treatments subjected to Tukey's test at $5 \%$ probability. For non-parametric data, we used the Kruskal-Wallis test. The chemical properties of the plants were compared across treatments and cycles. Data from three cycles and three treatments were used in a multiple regression analysis to identify possible nutrient associations with dry biomass and seed production. For the production of dry biomass of roots, the predictor variables were the nutrients in the roots $\left(\mathrm{N}_{\mathrm{r}}, \mathrm{P}_{\mathrm{r}}, \mathrm{K}_{\mathrm{r}}, \mathrm{S}_{\mathrm{r}}, \mathrm{Ca}_{\mathrm{r}}, \mathrm{Mg}_{\mathrm{r}}\right.$, and $\mathrm{Na}_{\mathrm{r}}$ ), while for the production of shoot biomass and seeds, the predictor variables were their respective nutrients $\left(\mathrm{N}_{\mathrm{pa}}, \mathrm{P}_{\mathrm{pa}}, \mathrm{K}_{\mathrm{pa}}, \mathrm{S}_{\mathrm{pa}}, \mathrm{Ca}_{\mathrm{pa}}, \mathrm{Mg}_{\mathrm{pa}}\right.$, and $\left.\mathrm{Na}_{\mathrm{pa}}\right)$. We used $\mathrm{R}$ software for statistical analysis (R CORE TEAM, 2013). 


\section{RESULTS AND DISCUSSION}

The irrigation treatments applied to the sunflowers during one or more of the crop cycles (Table 2) caused a significant variation in the plants' nutrient accumulation. The $\mathrm{K}(\mathrm{C} 1), \mathrm{Na}(\mathrm{C} 1$ and $\mathrm{C} 2)$, and $\mathrm{P}(\mathrm{C} 1$ and $\mathrm{C} 3)$ concentrations in roots were affected by the produced water in relation to the groundwater irrigation $(\mathrm{GW})$. Nutrient variation was highest in shoot tissues, with significant differences in $\mathrm{N}(\mathrm{C} 1$ and $\mathrm{C} 3), \mathrm{S}(\mathrm{C} 1), \mathrm{Mg}(\mathrm{C} 1$ and $\mathrm{C} 2), \mathrm{K}(\mathrm{C} 3)$, $\mathrm{Na}(\mathrm{C} 1, \mathrm{C} 2$, and $\mathrm{C} 3)$, and $\mathrm{P}(\mathrm{C} 1, \mathrm{C} 2$, and $\mathrm{C} 3)$. Only $\mathrm{Ca}(\mathrm{C} 2$ and $\mathrm{C} 3)$ varied in the seeds. As in other wastewater studies (PEREIRA et al., 2011; RODDA et al, 2011; SHAHBAZ et al., 2011; KHAJANCHILAL; MINHAS; YADAV, 2015), the produced water significantly altered the chemical composition of the sunflower roots, shoots, and seeds. However, nutrient content variation in the plant tissues reflected the water treatment, which is in agreement with the observations of Kiziloglu et al. (2008). The OPW contributed to high concentrations of N, P, Ca, and $\mathrm{Mg}$ in the shoots, whereas the FPW raised not only the concentration of $\mathrm{K}$ in the shoots but also the concentration of $\mathrm{Na}$ in the roots and shoots. In contrast, the $\mathrm{S}$ uptake was lowest in plants irrigated with OPW and FPW.

Table 2. Nutrient content in roots, shoots, and seeds of sunflowers irrigated with reverse osmosis-treated (OPW), filtertreated produced water (FPW), and groundwater (GW) in three crop cycles.

\begin{tabular}{|c|c|c|c|c|c|c|c|c|c|c|}
\hline \multirow{2}{*}{ Nutrient } & \multirow{2}{*}{ Treatment } & \multicolumn{3}{|c|}{ Roots } & \multicolumn{3}{|c|}{ Shoots } & \multicolumn{3}{|c|}{ Seeds } \\
\hline & & $\mathrm{C} 1$ & $\mathrm{C} 2$ & $\mathrm{C} 3$ & $\mathrm{C} 1$ & $\mathrm{C} 2$ & $\mathrm{C} 3$ & $\mathrm{C} 1$ & $\mathrm{C} 2$ & $\mathrm{C} 3$ \\
\hline \multirow{3}{*}{$\begin{array}{c}\mathrm{N} \\
\left(\mathrm{g} \mathrm{kg}^{-1}\right)\end{array}$} & OPW & $6.66 \mathrm{Ba}$ & $7.78 \mathrm{Ba}$ & $11.85 \mathrm{Aa}$ & $11.03 \mathrm{Bb}^{1}$ & $17.12 \mathrm{Aa}$ & $10.11 \mathrm{Ba}^{1}$ & $34.63 \mathrm{Ba}$ & $50.91 \mathrm{Aa}$ & $26.90 \mathrm{Ba}$ \\
\hline & FPW & 8.40Aa & 7.91Aa & $10.54 \mathrm{Aa}$ & $17.56 \mathrm{Aa}$ & $11.05 \mathrm{Ba}$ & $10.22 \mathrm{Ba}$ & $36.8 \mathrm{Aa}$ & 38.49Aa & $25.82 \mathrm{Ba}$ \\
\hline & GW & 7.97Aa & 7.12Aa & $9.41 \mathrm{Aa}$ & $20.73 \mathrm{Aa}$ & $9.69 \mathrm{Ba}$ & $7.60 \mathrm{Cb}$ & $37.73 \mathrm{Ba}$ & $45.65 \mathrm{Aa}$ & $27.24 \mathrm{Ca}$ \\
\hline \multirow{3}{*}{$\begin{array}{c}\mathrm{P} \\
\left(\mathrm{g} \mathrm{kg}^{-1}\right)\end{array}$} & OPW & $1.37 \mathrm{Bb}$ & $2.03 \mathrm{Ba}$ & $3.43 \mathrm{Aa}$ & $2.69 \mathrm{Bc}$ & $4.13 \mathrm{Aa}$ & $3.00 \mathrm{Ba}$ & $6.84 \mathrm{Aa}$ & $6.41 \mathrm{Aa}$ & $6.44 \mathrm{Aa}$ \\
\hline & FPW & $1.94 \mathrm{Aab}$ & $1.61 \mathrm{Aa}$ & $1.65 \mathrm{Ab}$ & 4.11Ab & $2.07 \mathrm{Bb}$ & $1.34 \mathrm{Bb}$ & 7.47Aa & $5.27 \mathrm{Ba}$ & $5.46 \mathrm{Ba}$ \\
\hline & GW & $2.30 \mathrm{Aa}$ & $1.66 \mathrm{Aa}$ & $1.63 \mathrm{Ab}$ & 5.70Aa & $2.33 \mathrm{Bb}$ & $1.79 \mathrm{Bb}$ & 7.40Aa & $5.63 \mathrm{Ba}$ & $5.60 \mathrm{Ba}$ \\
\hline \multirow{3}{*}{$\underset{\left(\mathrm{g} \mathrm{kg}^{-1}\right)}{\mathrm{K}}$} & OPW & $21.86 \mathrm{Aa}$ & $6.43 \mathrm{Ba}$ & $6.42 \mathrm{Ba}$ & $40.40 \mathrm{Aa}$ & $40.03 \mathrm{Aa}$ & $46.56 \mathrm{Aab}^{1}$ & $9.15 \mathrm{Aa}$ & $9.71 \mathrm{Aa}$ & $7.55 \mathrm{Aa}$ \\
\hline & FPW & $12.92 \mathrm{Ab}$ & 7.43Ba & $6.36 \mathrm{Ba}$ & 43.47Aa & $44.88 \mathrm{Aa}$ & 47.88Aa & $9.12 \mathrm{Aa}$ & $9.94 \mathrm{Aa}$ & $6.74 \mathrm{Ba}$ \\
\hline & GW & $13.73 \mathrm{Ab}$ & 7.38Ba & $4.81 \mathrm{Ba}$ & $43.20 \mathrm{Aa}$ & $43.33 \mathrm{Aa}$ & $41.53 \mathrm{Ab}$ & $8.38 \mathrm{Ba}$ & $9.78 \mathrm{Aa}$ & $6.87 \mathrm{Ca}$ \\
\hline \multirow{3}{*}{$\begin{array}{c}\mathrm{S} \\
\left(\mathrm{g} \mathrm{kg}^{-1}\right)\end{array}$} & OPW & $2.12 \mathrm{Aa}$ & $2.93 \mathrm{Aa}$ & 2.34Aa & $1.43 \mathrm{Cb}^{1}$ & $3.41 \mathrm{Aa}$ & $2.58 \mathrm{Ba}$ & 3.06Aa & $3.54 \mathrm{Aa}$ & $1.90 \mathrm{Aa}$ \\
\hline & FPW & 2.67Aa & $3.16 \mathrm{Aa}$ & $1.40 \mathrm{Ba}$ & $1.76 \mathrm{Bb}$ & $3.28 \mathrm{Aa}$ & $1.53 \mathrm{Ba}$ & 2.09Ba & $3.40 \mathrm{Aa}$ & $1.99 \mathrm{Ba}$ \\
\hline & GW & $1.50 \mathrm{Ba}$ & $3.26 \mathrm{Aa}$ & $1.90 \mathrm{Ba}$ & $2.88 \mathrm{ABa}$ & $3.49 \mathrm{Aa}$ & $1.62 \mathrm{Ba}$ & $2.42 \mathrm{Ba}$ & $3.57 \mathrm{Aa}$ & $1.90 \mathrm{Ba}$ \\
\hline \multirow{3}{*}{$\begin{array}{c}\mathrm{Ca} \\
\left(\mathrm{g} \mathrm{kg}^{-1}\right)\end{array}$} & OPW & $6.56 \mathrm{Ba}$ & $12.87 \mathrm{Aa}$ & $10.81 \mathrm{Aa}$ & $19.53 \mathrm{Ba}$ & $34.70 \mathrm{Aa}$ & $24.05 \mathrm{Ba}$ & $3.92 \mathrm{Ba}$ & $8.63 \mathrm{Ab}$ & $4.15 \mathrm{Ba}$ \\
\hline & FPW & $6.48 \mathrm{Ba}$ & 13.10Aa & 7.35Aa & $21.89 \mathrm{Aa}$ & $30.26 \mathrm{Aa}$ & 27.30Aa & $3.75 \mathrm{Ba}$ & 8.89Aab & $2.10 \mathrm{Cb}$ \\
\hline & GW & $6.43 \mathrm{Aa}$ & $13.59 \mathrm{Aa}$ & $8.55 \mathrm{Aa}$ & $22.7 \mathrm{Ba}$ & $28.41 \mathrm{Aa}$ & $19.74 \mathrm{Ba}$ & $4.78 \mathrm{Ba}$ & $9.31 \mathrm{Aa}$ & $2.82 \mathrm{Cb}$ \\
\hline \multirow{3}{*}{$\underset{\left(\mathrm{g} \mathrm{kg}^{-1}\right)}{\mathrm{Mg}}$} & OPW & 2.59Aa & $2.65 \mathrm{Aa}$ & $2.83 \mathrm{Aa}$ & $3.82 \mathrm{~B}^{1} \mathrm{~b}$ & $9.30 \mathrm{Aa}$ & 7.41Aa & $5.23 \mathrm{Aa}$ & 4.67Aa & 5.08Aa \\
\hline & FPW & $2.67 \mathrm{Aa}$ & $2.13 \mathrm{Aa}$ & 2.29Aa & $4.42 \mathrm{Ab}$ & $3.37 \mathrm{Ab}$ & $5.65 \mathrm{Aa}$ & $5.12 \mathrm{Aa}$ & $4.45 \mathrm{ABa}$ & $3.21 \mathrm{Ba}$ \\
\hline & GW & $2.41 \mathrm{Aa}$ & $2.24 \mathrm{Aa}$ & $1.74 \mathrm{Aa}$ & $7.24 \mathrm{~A}^{1} \mathrm{a}$ & $3.77 \mathrm{Bb}$ & $4.54 \mathrm{Ba}$ & $5.24 \mathrm{Aa}$ & $4.16 \mathrm{Aa}$ & $3.90 \mathrm{Aa}$ \\
\hline \multirow{3}{*}{$\underset{\left(\mathrm{g} \mathrm{kg}^{-1}\right)}{\mathrm{Na}}$} & OPW & $10.08 \mathrm{~B}^{1} \mathrm{c}$ & $16.88 \mathrm{Ab}$ & $17.78 \mathrm{Aa}$ & $0.88 \mathrm{Ab}$ & $0.69 \mathrm{Ab}$ & $1.86 \mathrm{Ab}$ & $0.19 \mathrm{Aa}$ & $0.02 \mathrm{Ba}$ & $0.02 \mathrm{Ba}$ \\
\hline & FPW & $27.99 \mathrm{Aa}$ & $24.7 \mathrm{Aa}$ & $25.02 \mathrm{Aa}$ & $3.02 \mathrm{Ba}$ & $5.40 \mathrm{Ba}$ & 9.88Aa & $0.24 \mathrm{Aa}$ & $0.02 \mathrm{Ba}$ & $0.05 \mathrm{Ba}$ \\
\hline & GW & $22.08 \mathrm{Ab}$ & $15.22 \mathrm{Ab}$ & $21.90 \mathrm{Aa}$ & $1.07 \mathrm{Ab}$ & $1.65 \mathrm{Ab}$ & $3.60 \mathrm{Ab}$ & $0.19 \mathrm{Aa}$ & $0.03 \mathrm{Ba}$ & $0.02 \mathrm{Ba}$ \\
\hline
\end{tabular}

${ }^{1}$ Kruskal-Wallis test. Different uppercase letters in the same row indicate significant differences between the means of the Cycles. Different lowercase letters in the same column indicate significant differences between treatments with Water. C1, $\mathrm{C} 2$, and $\mathrm{C} 3$ indicate the first, second, and third crops, respectively. 
Liu, Guo, and Shi (2010) found that the alkaline and saline conditions of the water affected the levels of nutrients in the sunflower roots and shoots, for example by reducing the $\mathrm{N}$ content. The highest concentration of $\mathrm{N}$ in the shoots of plants irrigated with OPW can be attributed to its low salt content, as the alkalinity of the various types of water used in the study was similar (Table 1). The same explanation can be given for the higher levels of $\mathrm{Ca}$ and $\mathrm{Mg}$ in the shoots of plants irrigated with OPW.

The highest accumulation of $\mathrm{K}$ occurred in plant roots irrigated with OPW, which had low salinity, and in the shoots of plants irrigated with FPW, which had high salinity. These results are in agreement with the results of Liu, Guo, and Shi (2010) and Shaheen et al. (2013). However, Liu, Guo, and Shi (2010) observed elevated levels of P in the roots and shoots (stems and leaves) with increasing salinity. Therefore, the $\mathrm{P}$ levels observed in the various tissues in this study may not be associated the salinity of the water because the $\mathrm{P}$ content was highest in plants irrigated with OPW (Table 2), which showed lower levels of $\mathrm{Na}$ (Table 1). This interpretation is in agreement with the results obtained by Shahbaz et al. (2011), who found that salinity does not interfere with the absorption of $\mathrm{P}$ by sunflower plants.

The highest accumulation of $\mathrm{Na}$, which occurred in plants irrigated with FPW, may be associated with the higher salinity of the water (SHAHBAZ et al., 2011). Increased $\mathrm{Na}$ content due to saline water irrigation was observed in other crops, such as okra and tomatoes (KAMALULDEEN et al., 2014). The higher amount of $\mathrm{Na}$ in the water and its subsequent uptake by plants is the principal difficulty with the reuse of produced water that has been filtered. This effect has also been observed with other types of wastewater (HEIDARPOUR et al., 2007; MORUGÁNCORONADO et al., 2011; SHAHBAZ et al., 2011; SOU/DAKOURÉ et al., 2013). Salt stress negatively influences the development of the plant because high levels of $\mathrm{Na}$ has a phytotoxic effect on the plant (SHAHEEN et al., 2013) and decreases the accumulation of essential nutrients in the plants' tissues (PEREIRA et al., 2011; SHAHBAZ et al., 2011). However, the negative effect depends upon the ability of the species to tolerate a high $\mathrm{Na}$ content in their tissues, or even due to the presence of ions that can buffer the phytotoxic effect of $\mathrm{Na}$ (KAMALULDEEN et al., 2014).

The OPW increased $\mathrm{N}, \mathrm{P}, \mathrm{Ca}$, and $\mathrm{Na}$ concentrations in roots and $\mathrm{Mg}$ in shoots, but reduced $\mathrm{K}$ in the roots and $\mathrm{N}, \mathrm{Ca}$, and $\mathrm{Na}$ in seeds after three successive crop cycles. The FPW negatively affected nutrient accumulation in the sunflowers because the $\mathrm{Na}$ content in shoots increased and the $\mathrm{K}$ and $\mathrm{S}$ concentration in the roots, $\mathrm{N}$ and $\mathrm{P}$ in the shoots, and $\mathrm{N}, \mathrm{Ca}, \mathrm{P}, \mathrm{Mg}, \mathrm{Na}$, and $\mathrm{K}$ in the seeds reduced with each subsequent crop cycle (Table 2).

The effects of wastewater on nutrient accumulation in plant tissue after consecutive crop cycles were variable, as observed by other authors (RUSAN; HINNAWI; ROUSAN, 2007; RODDA et al., 2011). In this study, plants irrigated with OPW showed the greatest accumulation of nutrients in plant tissues after three consecutive crop cycles, with $\mathrm{Ca}, \mathrm{Na}, \mathrm{N}, \mathrm{P}$, and $\mathrm{Mg}$ levels increasing in the roots. In contrast, FPW adversely affected the plants, as $\mathrm{Na}$ tends to accumulate over time, a situation that can induce nutritional imbalances and damage plant growth (MORUGÁN-CORONADO et al., 2011; PEREIRA et al., 2011; SOU/DAKOURÉ et al., 2013). Additionally, $N$ and $P$ levels in the shoots and $\mathrm{Ca}, \mathrm{Mg}, \mathrm{K}, \mathrm{Na}$, and $\mathrm{P}$ levels in the seeds of plants irrigated with FPW decreased with subsequent cultivations. The FPW, with high salinity, raised the $\mathrm{Na}$ content in the soil throughout the cultivation period, thus affecting the uptake of nutrients by the plants (LIU; GUO; SHI, 2010; SHAHBAZ et al., 2011). The reduction of the $K$ content throughout the three crop cycles, regardless of the type of water used for irrigation (Table 2), may be due to the leaching of nutrients by the applied water (PEREIRA et al., 2011; SHAHBAZ et al., 2011).

Furthermore, in the second crop cycle, the concentrations of $\mathrm{P}, \mathrm{S}$, and $\mathrm{Ca}$ were higher in the shoots of plants irrigated with OPW; the concentration of $\mathrm{S}$ was higher in the roots and seeds of plants irrigated with FPW; and the concentrations of $\mathrm{Ca}$ and $\mathrm{S}$ in the shoots and the concentration of $\mathrm{S}$ were higher in the seeds of plants irrigated with GW (Table 2). In this cycle, in addition to the water supplied via irrigation, subsequent precipitation occurred in the experimental area $(483 \mathrm{~mm})$. As a result, salts were leached from the soil profile and the lower salinity favored the absorption of nutrients (MORUGÁN-CORONADO et al., 2011; PEREIRA et al., 2011; SOU/DAKOURÉ et al., 2013). Therefore, the detrimental effect that salinity has on the yield can be ameliorated by precipitation. An alternative method is the frequent leaching of soil salt through irrigation (GENGMAO; MEHTA; ZHAOPU, 2010).

$\mathrm{Ca}_{\mathrm{r}}$ and $\mathrm{K}_{\mathrm{r}}$ accounted for an $83 \%(\mathrm{P}<0,001)$ change in the observed root production, with $\mathrm{Ca}_{\mathrm{r}}$ influencing it negatively and $\mathrm{K}_{\mathrm{r}}$ influencing it positively (Table 3 ). Shoot production was positively affected by $K_{r}$ and $P_{p a}$ and negatively affected by $\mathrm{Ca}_{\mathrm{r}}, \mathrm{Na}_{\mathrm{r}}$, and $\mathrm{Mg}_{\mathrm{pa}}\left(\mathrm{R}^{2}=0.89 ; \mathrm{P}<0.001\right)$. Seed yield was positively influenced by $\mathrm{Ca}_{\mathrm{r}}, \mathrm{K}_{\mathrm{r}}, \mathrm{P}_{\mathrm{r}}, \mathrm{K}_{\mathrm{pa}}$, and $\mathrm{N}_{\mathrm{pa}}$ and negatively influenced by $\mathrm{Na}_{\mathrm{pa}}, \mathrm{P}_{\mathrm{pa}}, \mathrm{S}_{\mathrm{pa}}$, and $\mathrm{N}_{\mathrm{r}}$ $\left(\mathrm{R}^{2}=0.51 ; \mathrm{P}<0.05\right)$ 
Table 3. Predicted production equations according to nutrient levels in different plant parts.

\begin{tabular}{|c|c|c|c|}
\hline Biomass & Model equation & $\mathrm{R}^{2}$ & $\mathrm{P}$ \\
\hline Root & $\mathrm{Y}=7.62-0.72 \times\left(\mathrm{Ca}_{\mathrm{r}}\right)+1.3 \times\left(\mathrm{K}_{\mathrm{r}}\right)$ & 0.83 & $<0.001$ \\
\hline Shoot & $\mathrm{Y}=102.12-7.34 \times\left(\mathrm{Ca}_{\mathrm{r}}\right)+7.75 \times\left(\mathrm{K}_{\mathrm{r}}\right)-6.09 \times\left(\mathrm{Mg}_{\mathrm{pa}}\right)-1.98 \times\left(\mathrm{Na}_{\mathrm{r}}\right)+24.43\left(\mathrm{P}_{\mathrm{pa}}\right)$ & 0.89 & $<0.001$ \\
\hline Seeds & $\begin{array}{l}\mathrm{Y}=35.89+0.58 \times\left(\mathrm{Ca}_{\mathrm{r}}\right)+0.44 \times\left(\mathrm{K}_{\mathrm{pa}}\right)+1.15 \times\left(\mathrm{K}_{\mathrm{r}}\right)-0.91 \times\left(\mathrm{Na}_{\mathrm{pa}}\right)+1.18 \times\left(\mathrm{N}_{\mathrm{pa}}\right) \\
-3.07 \times\left(\mathrm{N}_{\mathrm{r}}\right)-6.69 \times\left(\mathrm{P}_{\mathrm{pa}}\right)+10.11 \times\left(\mathrm{P}_{\mathrm{r}}\right)-4.24 \times\left(\mathrm{S}_{\mathrm{pa}}\right)\end{array}$ & 0.51 & $<0.05$ \\
\hline
\end{tabular}

Plant growth was affected by the nutrients, particularly by the content and distribution in the different parts of the plant (roots, shoots, and seeds). For example, $\mathrm{K}$ in the roots and $\mathrm{P}$ in the shoots are important for plant growth, while higher levels of $\mathrm{Na}$ in the roots caused reduced biomass production (Table 3). Although the production of seeds can increase with elevated levels of $\mathrm{Ca}, \mathrm{K}$, and $\mathrm{P}$ in the roots and $\mathrm{K}$ and $\mathrm{N}$ in the shoots, production decreases when there is a high concentration of $\mathrm{N}$ in the roots and of $\mathrm{Na}, \mathrm{P}$, and $\mathrm{S}$ in the shoots (Table 3 ).

When $\mathrm{Na}$ is present in plant tissues, it may serve as the main regulator of root, shoot, and seed biomass production, as noted by Rusan, Hinnawi, and Rousan, (2007), Gengmao, Mehta, and Zhaopu (2010), Morugán-Coronado et al. (2011), Sou/ Dakouré et al. (2013), and Kamaluldeen et al. (2014). As shown in Table 2, it varies more between the various types of irrigation water than any other element. The accumulation of $\mathrm{Na}$ in roots and shoots reduces the photosynthetic ability of plants (SHAHEEN et al. 2013) and negatively affects the nutritional aspects of the plants (PEREIRA et al, 2011; SHAHBAZ et al, 2011), both of which are factors that can reduce plant growth. FPW irrigation induces the greatest accumulation of $\mathrm{Na}$ in roots and shoots, reducing the growth and production of the sunflowers. However, other ions may be detrimental to sunflowers production. For instance, the $\mathrm{P}$ in the shoots correlated negatively with seed production. The negative effect of $\mathrm{P}$ on seed production has been observed in other crops (okra and tomatoes) as well. This is probably due to $\mathrm{P}$ reducing the absorption of micronutrients, which play an important role in the plants' biochemical process (KAMALULDEEN et al., 2014).

\section{CONCLUSION}

The chemical composition of the sunflower plants is altered by the treated produced water drip irrigation, but the effect on the nutrient concentration in the crop depends on the treatment. The use of reverse osmosis-treated produced water favors the crop by improving the nutritional condition of the plants $(\mathrm{Ca}, \mathrm{N}, \mathrm{P}$, and $\mathrm{Mg}$ ); while the use of filtered produced water reduces nutrient accumulation in the plants. Furthermore, filtered produced water induces the accumulation of $\mathrm{Na}$ in the sunflowers. Under controlled conditions, it is possible to reuse the reverse osmosis-treated produced water in agriculture, but this method requires further longterm research to understand its cumulative effect on the chemical and biological properties of the soil and crop production.

\section{ACKNOWLEDGMENTS}

This study is part of a project on the reuse of produced water for irrigation. The authors thank Petrobras for financial support, the Embrapa Tropical Agroindustry for logistics and laboratory facilities, and and CNPq for scholarships.

\section{REFERENCES}

AL-HALEEM, A. A.; ABDULAH H. H.; SAEED, E. A-J. Components and Treatments of Oilfield Produced Water. Al-Khwarizmi Engineering Journal, Baghdad, v. 6, n. 1, p. 24-30, 2010.

BEDBABIS, S. et al. Effect of irrigation with treated wastewater on soil chemical properties and infiltration rate. Journal of Environmental Management, Florida, v. 133, n. 2, p. 45-50, 2014.

CHATZAKIS, M. K. et al. Irrigation of castor bean (Ricinus communis L.) and sunflower (Helianthus annuus L.) plant species with municipal wastewater effluent: impacts on soil properties and seed yield. Water, Basel, v. 3, n. 4, p. 1112-1127, 2011.

CIRELLI, G. L. et al. Treated municipal wastewater reuse in vegetable production. Agricultural Water Management, Netherlands, v. 104, n. 2, p. 163-170, 2012.

FRENKEN, K.; KIERSCH, B. 2011. Monitoring agricultural water use at country level: Experiences of a pilot project in Benin and Ethiopia. FAO FOOD AND AGRICULTURE ORGANIZATION OF THE UNITED NATIONS: Land and Water Division. Land And Water Discussion Paper, 9. 
Disponível em: www.fao.org/nr/water/docs/FAO. Acesso em: 20 Jan. 2015.

GENGMAO, Z.; MEHTA, S. K.; ZHAOPU, L. Use of saline aquaculture wastewater to irrigate salttolerant Jerusalem artichoke and sunflower in semiarid coastal zones of China. Agricultural Water Management, Netherlands, v. 97, n. 12, p. 1987-1993, 2010.

HEIDARPOUR, M. et al. The effects of treated wastewater on soil chemical properties using subsurface and surface irrigation methods. Agricultural Water Management, Netherlands, v. 90, n. 1, p. 87-94, 2007.

KAMALULDEENA, J. et al. Uptake and distribution of ions reveal contrasting tolerancemechanisms for soil and water salinity in okra (Abelmoschus esculentus) and tomato (Solanum esculentum). Agricultural Water Management, Netherlands, v. 146, n. 7, p. 95-104, 2014.

KHAJANCHI -LAL， P. S.; MINHAS， P. S.; YADAV, R. K. Long-term impact of wastewater irrigation and nutrient rates II. Nutrient balance, nitrate leaching and soil properties under peri-urban cropping systems. Agricultural Water Management, Netherlands, v. 156, n. 6, p. 110-117, 2015.

KIZILOGLU, F. M. et al. Effects of untreated and treated wastewater irrigation on some chemical properties of cauliflower (Brassica olerecea L. var. botrytis) and red cabbage (Brassica olerecea L. var. rubra) grown on calcareous soil in Turkey. Agricultural Water Management, Netherlands, v. 95 , n. 6, p. 716-724, 2008

LIU, J.; GUO, W. Q.; SHI, D. C. Seed germination, seedling survival, and physiological response of sunflowers under saline and alkaline conditions. Photosynthetica, Lysolage, v. 48, n. 2, p. 278-286, 2010.

MELO, M. et al. Advanced performance evaluation of a reverse osmosis treatment for oilfield produced water aiming reuse. Desalination, Amsterdam, v. 250, n. 3, p. 1016-1018, 2010.

MORUGÁN-CORONADO, A. et al. Short-term effects of treated wastewater irrigation on Mediterranean calcareous soil. Soil \& Tillage Research, Netherlands, n. 1, v. 112, p. 18-26, 2011.

NASCIMENTO, J. F. et al. Tratamento de águas de produção para uso em irrigação. Rio de Janeiro: CENPS/PDP/TPAP, 2006. 57 p. (Relatório técnico interno, 18).
PEREIRA, B. F. F. et al. Reclaimed wastewater: Impact on soil-plant system under tropical conditions. Journal of Hazardous Materials, Netherlands, v. 192, n. 1, p. 54-61, 2011.

R CORE TEAM. R: A Language and Environment for Statistical Computing. Organização: R Foundation for Statistical Computing. Vienna, Austria. 2013. Disponível em: http://www.Rproject.org. Acesso em: Jan. 2014.

RODDA, N. et al. Use of domestic greywater for small-scale irrigation of food crops: Effects on plants and soil. Physics and Chemistry of the Earth, United Kingdom, v. 36, n. 14, p. 1051-1062, 2011.

RUSAN, M. J. M.; HINNAWI, S.; ROUSAN, L. Long term effect of wastewater irrigation of forage crops on soil and plant quality parameters. Desalination, Amsterdam, v. 215, n. 1, p. 143-152, 2007.

SHAHBAZ, M. et al. Salt-induced modulation in growth, photosynthetic capacity, proline content and ion accumulation in sunflower (Helianthus annuus L.). Acta Physiologiae Plantarum, Poland, v. 33, n. 4, p. 1113-1122, 2011.

SHAHEEN, S. et al. Salt stress affects water relations, photosynthesis, and oxidative defense mechanisms in Solanum melongena L. Journal of Plant Interactions, United Kingdom, v. 8, n. 1, p. 85-96, 2013.

SILVA, F. C. Manual de análises químicas de solos, plantas e fertilizantes. 2. ed. Brasília, DF: EMBRAPA, 2009. 627 p.

SINGH, P. K. et al. Effects of sewage wastewater irrigation on soil properties, crop yield and environment. Agricultural Water Management, Netherlands, v. 103, n. 1, p. 100-104, 2012.

SOU/DAKOURÉ, M. Y. et al. Impacts of irrigation with industrial treated wastewater on soil properties. Geoderma, Netherlands, v. 201, n. 6, p. 31-39, 2013.

$\mathrm{XU}, \mathrm{J}$. et al. Impact of long-term reclaimed wastewater irrigation on agricultural soils: A preliminary assessment. Journal of Hazardous Materials, Netherlands, v. 183, n. 1. p. 780-786, 2010 